\title{
The Challenges of Global Migration in Perspective of International Humanitarian Law: Reframing the Refugees in Kepulauan Riau, Indonesia
}

\author{
Dhani Akbar ${ }^{1 *}$ Dodi Lesmana ${ }^{2}$ Gulmok Simbolon ${ }^{2}$ \\ ${ }^{1}$ Center of South East Asia and Border Studies Universitas Maritim Raja Ali Haji, Tanjungpinang, Indonesia \\ ${ }^{2}$ Department of International Relation, Faculty of Social and Political Science, Universitas Maritim Raja Ali \\ Haji \\ *Corresponding author.Email: akbardhani@umrah.ac.id
}

\begin{abstract}
the principle of humanity, distinction proportionally, precautions, and also prohibition of unnecessary suffering, with the main legal instruments 1907 Hague Regulations, 1949 Geneva Conventions, 1977 Additional Protocols and Customary IHL, Indonesia is one of the parties that did not ratify the 1951 Convention Relating to The status of Refugees and the 1967 Protocol Relating to the Status of Refugees. However, Indonesia still has willingness to conduct cooperation, in this case with the United Nations High Commissioner for Refugees (UNHCR), International Organization of Migration (IOM) and International Committee of Red Cross (ICRC), to achieve world peace and improve the welfare of the world community. This study aims to examine the problem faced by Indonesian government, especially in border area, case study in Kepulauan Riau Province that has approximately 500 refugees in Bintan Island and 1,000 in Batam City under surveillance of IOM and UNHCR. This study uses Theory of Reasoned Action (TRA) as the main approach to analyze the phenomenon. In the results and discussion, Indonesia is a republic that is very supportive of the welfare of immigrants, refugees and asylum seekers, even not able to abandon the fact that Indonesia as a country that is currently experiencing on immigrants, refugees, or asylum seekers in a great number. This caused by lack of supporting facility, increasing poverty, and also a high number of unemployment. Refugees defined as protected person, and prohibited to be repatriated and deported, still have faith in humanity, and international cooperation need to meet a suitable agreement. Indonesia should give several statements to address this issue; first, the government should review the recent growth of immigrant, refugees and asylum seekers in the entire location, especially in border region where need primary attention; second, the government should find the way on supporting the life of its people whom need help by inviting more cooperation between nations; third, government should have willingness to have a better place to the refugees.
\end{abstract}

Keywords: migration, refugees, challanges, behavior, society.

\section{INTRODUCTION}

Since Indonesia is not a party to the Convention on the Status of Refugees (1951), issues involving them are considered as immigration matters. Furthermore, along with the scope of immigration, the legislation does not totally address the issues of asylum seekers and refugees[1]. However, Indonesia still opens its doors and accepts refugees in a certain period of time to live before being transferred to a third country. Currently, Insights provided into the more general situation of almost
13,000 adult asylum seekers and refugees in Indonesia registered with the United Nations High Commissioner for Refugees (UNHCR) offices in Indonesia[2]. It is compulsory that refugees who come from various countries have different characters.

The existence of these differences in character possibly also causes differences in behavior in dealing

with the environment where they live in their new place. United Nations High Commissioner for 
Refugees (UNHCR) as an organization that deals with refugees by providing various activities given to refugees in the hope of bringing change in the lives of refugees. Furthermore, refugees in Indonesia are not permitted to work and have limited access to education and affordable healthcare[3]. With the various regulations, norms, customs and cultures that exist in the area where they are placed, of course, it is hoped that the refugees can obey the regulations that are ready accordingly. However, the dynamics that occur in the field are different. It turned out that several problems arose which later received responses from the community for review by the government.

\section{RESEARCH METHOD}

This research was conducted using Theory of Reasoned Action (TRA) where will be used in finding primary and secondary data. The TRA propose that behavior based on the concept of intention. Intention is the extent to which someone is ready to engage in a certain behavior or the likelihood that someone will engage in a particular behavior[4]. Primary data is obtained through the community and related actors and secondary data is obtained from journals and literature related to this research.

By using qualitative methods to obtain data, the authors interviewed related actors both government and non-government and opened a general discussion forum and gave questionnaires and survey surveys to the community.

\section{FINDINGS AND DISCUSSION}

Based on the Decree on December 22, 1993 the National Human Rights Commission (KOMNAS HAM) was formed which aims to, first, assist in developing conditions conducive to the implementation of human rights in accordance with Pancasila, the 1945 Constitution, and the UN Charter, and the Universal Declaration of Human Rights, and second, increase the protection of human rights in order to support the realization of national development goals, namely the development of Indonesian people as a whole and the development of Indonesian society as a whole[5]. However, problem of asylum seekers and refugees comes up as the third countries which often became shelters or even dismissal places for asylum seekers and refugees mostly have not ratified the convention, even though the principle for them is recognized as an international customary law, including Indonesia[6].

Asylum seekers and refugees in Indonesia, especially in the Kepulauan Riau province, since the historical perspective of Vietnamese refugees, have nevertheless allowed to remain in its territory and established open detention facilities on remote islands. Against initial plans to accommodate transmitting asylum seekers only temporarily, most of them have spent several years in Indonesia, not least because the UNHCR and the IOM covered all related costs[7]. However, nowadays, in the case of Batam and Bintan, people are questioning why these refugees had to be placed in their area. so that arises their curiosity towards the refugees. Lots of people think that refugees are people who should be pitied, cared for and also given special treatment. which in the end the refugees and the community became more close and there were no boundaries. Indonesia should establish a legal framework that distinguishes specifically illegal migrants to asylum seekers and refugees[8].

As a result of the proximity of refugees and the community, problems often happen. One of them is the ownership of motorized vehicles that the refugees should not be allowed to drive because they do not have a driver's license., There are also other cases include violations of social norms which are considered serious violations, such as immoral acts, prostitution.

Of the 11 (eleven) cases that occurred, most of these cases were related to immoral acts. One of the cases that has become the spotlight from various circles is that there were some refugees who were related to wives of local residents. It was also found that when there was a relationship between the refugees and local women, the refugees used the vehicle belonging to the local woman to travel and it can be said that the route was very long which even left the Bintan Regency area and entered the Tanjungpinang City area, as it was found that the The refugees went to fitness centers in Tanjungpinang City. This is an offense because in reality these refugees do not have complete driving documents.

Many actors also spoke out related to issues that are currently in the public spotlight, such as from the Bintan Regency Police, the Tanjungpinang Immigration Detention Center (RUDENIM), as well as several government officials and other communities. One of the statements from the Head of Intelligence and Security of the Bintan Police in relation to this case, appealed to the public to 
increase their faith and fortify themselves from refugees who try to seduce local people or women. He also said that the majority of local women who still have the mindset of having a handsome or handsome face will improve their offspring and the fact that foreigners are more attractive, make the refugees feel that it is not difficult to conquer or attract these local women.

The head of the Tanjungpinang Immigration Detention Center (RUDENIM) also said that this problem could occur due to the interaction that occurred between refugees or asylum seekers with the local community, especially local women who were often victims. The Head of the Rudenim also said that the attitude of the residents who were too friendly, such as putting refugees into their homes could be misinterpreted by the refugees. He said that the immoral cases that occurred were not only the fault of either party. "It's like there is a supply and demand," said the Head of the Tanjungpinang Rudenim. He also said that if the local people behaved casually, the refugees would not dare to behave differently.

Several statements and complaints were also expressed by local people who often saw several refugees still roaming at night outside Bhadra Resort. The refugees have violated the stipulated exit time rules, in which the refugees are allowed to leave from 6 a.m to 6 p.m or 12 hours. However, these regulations were often violated and were not obeyed by some refugees. There are even some local people who feel scared when they see refugees around them. This is based on the statement of one local community who is a gardener who feels uncomfortable gardening until late afternoon when the sun starts to set. Regarding the immoral case that occurred, the community even had a demonstration at Bhadra Resort, Bintan Regency due to local community anxiety about negative behavior or attitudes carried out by the refugees. However, not all opinions and what local people feel are all the same, there are several different opinions and views of local people regarding the presence of refugees around them. There are still some refugees, some of whom are still good in the environment where they live or are. There are also some of the refugees who adhere to the exit time regulations to return to the Community House or Bhadra Resort exactly as set for them.

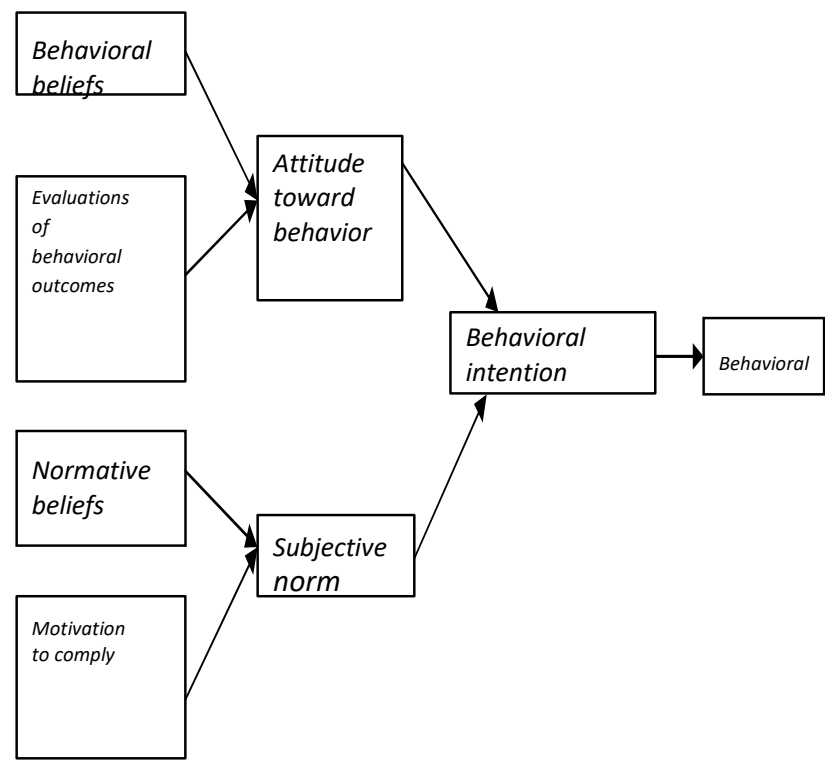

Fig.1. Theory of Reasoned Action

In line with this, positive speculation was conveyed by one of the government officials, namely the Head of the Toapaya sub-district who is in the vicinity not far from the location of the Community House where the refugees temporarily live, he said that not all refugees had negative behavior, especially refugees who interact with residents in the Toapaya District area. In fact, it can be said that there are still many refugees who socialize positively with their citizens, this can be seen from the behavior of some of these refugees who build good communication and help with activities organized by the sub-district and local residents. However, due to the cases and problems that occurred, namely some immoral cases committed by a number of refugees, the local community also thought that all refugees had the same attitude or behavior, causing feelings of worry and alertness by some local people.

Based on these data, the Theory of Reasoned Action (TRA) developed by Martin Fishbein and Icek Ajzen $(1975,1980)$ was used for this study, where this theory discusses attitudes and behavior. This theory connects belief, attitude, intention and behavior and in this Theory of Reasoned Action (TRA) there are 3 (three) general constructs, namely behavioral desires, attitudes, and subjective norms. . From these three constructs it is found that a person's behavior depends on one's attitude towards subjective norms and the desire of a person to do it or not. An important concept in this theory is the focus of attention (salience), which is to consider something that is considered important. Intetion is determined by subjective attitudes and norms. 
A person's intention or desire to perform a behavior determines whether or not the behavior will be carried out. Furthermore, the intention or desire to do or not do certain behaviors is influenced by two basic determinants, the first is related to attitude (attitude towards behavior) and the second is subjective norms. In an effort to reveal the influence of subjective attitudes and norms on intention to do or not to do behavior, as previously written. Attitudes come from behavioral beliefs, while subjective norms come from normative beliefs. The following is a schematic of Theory of Reasoned Action (TRA). Based on the above discussion, there are many challenges in accepting refugees in Indonesia, especially in Bintan district.

\section{CONCLUSION}

although Indonesia has not ratified the 1951 Convention Relating to The status of Refugees and the 1967 Protocol Relating to the Status of Refugees. but as a transfer country, Indonesia is obliged to accept a quota to accept refugees. The arrival of refugees in Indonesia has its own positive and negative sides. Where on the positive side, Indonesia can be a good country in the eyes of refugees. The negative side applies when the refugees have different characteristics and behavior from the Indonesian people, especially Batam and Bintan, Kepulauan Riau Province. the refugees are troubling the local community and also the government because of their bad attitude and behavior. the refugees committed immoral acts that resulted in community unrest. although of course all of that has a reason. where the community is also too close and removes restrictions on refugees.

The government often finds refugees riding motorbikes belonging to the community, whereas refugees should not be allowed to use motorbikes because the refugees do not have driving licenses.

Theory of Reasoned Action can be a reference because the theory discusses a person's attitudes and behavior. where in this case the writer discusses the attitude and behavior of the refugees and their challenges of global migration in perspective of international humanitarian law.

Finally, the government is advised to socialize more to both the refugees and the surrounding community. so as to create harmony between refugees and the surrounding community.

\section{REFFERENCES}

[1] A. Afriansyah and E. A. Zulfa, "Refugees Resettlement: a Review of Indonesian Laws and Practices," Indones. Law Rev., vol. 8, no. 2, p. 203, 2018.

[2] A. Missbach, "Accommodating asylum seekers and refugees in Indonesia: From immigration detention to containment in 'alternatives to detention," Refuge, vol. 33, no. 2, pp. 32-44, 2017.

[3] T. Brown, "After the Boats Stopped: Refugees Managing a Life of Protracted Limbo in Indonesia," Antropol. Indones. vol. 38, no. 1, pp. 34-50, 2017.

[4] M. Yzer, "Theory of Reasoned Action and Theory of Planned Behavior," Int. Encycl. Media Eff., pp. 1-7, 2017.

[5] T. H. Soeryabrata, "Juridical Review of the Refugees in Indonesia from the Human Rights Side and the Private Protection," vol. 140, no. Icleh, pp. 271-276, 2020.

[6] Fitria, "Perlindungan Hukum Bagi Pengungsi di Negara Ketiga: Praktik di Indonesia," J. Ilmu Huk. Univ. Padjadjaran, vol. 2, no. 1, pp. 105-125, 2015.

[7] A. Missbach, "Waiting on the islands of 'Stuckedness'. Managing asylum seekers in island detention camps in Indonesia from the late 1970 s to the early 2000s.," ASEAS - Austrian J. South-East Asian Stud., vol. 6, no. 2, pp. 281-306, 2013.

[8] D. Liliansa and A. Jayadi, "Should Indonesia Accede to The 1951 Refugee Convention and Its 1967 Protocol?," Indones. Law Rev., vol. 5, no. 3, p. 324, 2015. 